\title{
Duhovnost i duhovnik u palijativnoj skrbi
}

Vinka Bešlić*

s.vinka.beslic@gmail.com
UDK: 616-083:248

25:616-083

Pregledni rad / Review Primljeno: 28. rujna 2016. Prihvaćeno: 3. veljače 2017.

Polazeći od pojma duhovnosti u palijativnoj skrbi u ovom se članku na osnovu filozofsko-antropoloških spoznaja monističkog dualizma kao i osnovnih postavki triju velikih svjetskih religija o čovjekovu življenju i njegovoj usmjerenosti na Boga, želi osvijetliti značenje duhovnosti kao i ulogu duhovnika u palijativnoj skrbi. Duhovnost je važna sastavnica cjelokupne brige za dostojanstvo čovjekova življenja u najtežim situacijama bolesti ili starosti. Povećani interes za duhovnošću uopće, a napose u medicini, potvrđuje još jednom važnost holističkog pristupa čovjeku u palijativnoj skrbi. Monistički dualizam naglašava međusobno prožimanje duha, duše i tijela u čovjekovu življenju. Iz ovog proizlazi da duhovna dimenzija ima vrlo važnu ulogu. Tri najveće religije svijeta na njima svojstven način govore o smislu čovjekova života i smrti te o duhovnim vrijednostima, koje nadilaze čovjekov ovozemaljski život. U palijativnoj skrbi je bitna prisutnost duhovnika, koji će pokušati pomoći čovjeku u iznimno teškim situacijama za njega i njegovu obitelj, da im bude blizu, sluša ih, razumije i pokuša im otkriti istinske neprolazne vrijednosti. Duhovnik se sa svojim kompetencijama znanja $i$ iskustva stavlja na raspolaganje ne samo čovjeku u palijativnoj skrbi nego $i$ njegovoj rodbini kao i osoblju u palijativnom timu.

Ključne riječi: duhovnost, filozofsko-antropološka polazišta, kompetencije duhovnika, palijativna skrb, vjera.

\footnotetext{
* Dr. sc. Vinka Bešlić, na Sustavnom studiju duhovnosti u Remetama predaje kolegij Liturgijske duhovnosti; Česmičkoga 1, HR-10000 Zagreb.
} 


\section{Uvod}

Pitanja smisla čovjekova života, bolesti i smrti prate čovjeka tijekom čitave povijesti do danas te ga istovremeno potiču na traženje odgovora. Tragajući za njima čovjek ih nerijetko ne uspije pronaći ili nema vremena za njih ili se ona izgube u ritmu svakodnevice življenja te ostanu nerijetko predaleki. Ovo traženje postane u pojedinim trenucima čovjekova življenja izrazito intenzivno. Pitanjem smisla življenja, nastajanja i nestajanja bave se filozofija, teologija, biologija, ali i druge znanstvene discipline te pokušavaju svojim metodama pronaći odgovore na njih. Koji smisao ima čovjekov život, kada se susretne s neizlječivom bolesti? Završava li smrću sve? Postoji li neko drugo vrijeme ili neko drugo mjesto u kojima život ima drugačije zakonitosti? Ova pitanja su jednako izazovna u davnim stoljećima kao i danas, kako za pripadnike različitih religija isto tako i za one koji se tako ne izjašnjavaju. Iako suvremena znanstveno-tehnička civilizacija modernom čovjeku pruža odgovore na različita njegova pitanja, njegovo traganje za smislom života tim nije nimalo manje. Štoviše, opaža se izvjesna kriza duha, tj. neko metafizičko-antropološko gibanje »koje pokazuje tendenciju raskida s jednom jasnom vizijom o čovjeku i onom specifično ljudskom u čovjeku, tj. da je čovjek osoba (imago Dei) obdaren apsolutnim dostojanstvom i neotuđivim pravima. « $\mathrm{S}$ druge strane, se pojam duhovnost, koji je dugo vremena bio poznat skoro isključivo samo u crkvenim krugovima, u posljednja dva desetljeća susreće sve češće i u sekulariziranom svijetu. Velik broj ljudi reći će za sebe da su duhovni, ali nisu religiozni. Oni se žele ograditi od klasične religioznosti koju smatraju moralizirajućom, dogmatskom i preuskom, dok im je pojam duhovnost bliži, otvoreniji i širi. Zato je važno da se i u istraživanjima razlikuju pojmovi duhovnost i religioznost. ${ }^{2}$

Naši suvremenici čeznu za onom duhovnosti koja uzdiže kvalitetu čovjekova života na višu razinu. Ona duhovnost u kojoj oni pronalaze dubok smisao življenja, trpljenja i umiranja njima je neprocjenjivo blago.

Iako se u pojedinim europskim zemljama, napose u počecima organiziranja palijativne skrbi, zanemarivala duhovna dimenzija kao njen sastavni dio, vrlo brzo se uvidjelo, da je ona u palijativnoj skrbi od iznimno velike važnosti te danas čini jednu od važnih dimenzija njenog provođenja u bolničkim ustanovama, kućnoj njezi ili u domovima zdravlja. Zašto je ova dimenzija toliko važna u palijativnoj skrbi i koje kompetencije pritom treba imati duhovnik, pitanja su na koja ovaj članak pokušava odgovoriti.

1 Tonči MATULIĆ, Identitet, profesija i etika sestrinstva, Bogoslovska smotra, 77 (2007) 3, 727 744 , ovdje 738.

${ }^{2}$ Usp. Slobodan LOGA, Duhovnost, medicina, psihijatrija, u: Miro JAKOVLJEVIĆ (ur.), Duhovnost u suvremenoj medicini i psihijatriji, Zagreb, 2010, 1-6, ovdje 5. 


\section{O pojmu duhovnosti u palijativi}

Živimo u vremenu velikih nesigurnosti, povećanih terorističkih napada, globalnog zatopljenja, velikih poplava, novih nepoznatih bolesti, u kojemu naglo rastu tjeskoba i strah od budućnosti, ali i od sadašnjosti. U sklopu svih ovih i sličnih okolnosti može se primijetiti da naše vrijeme vapije za ljudima koji su spremni čovjeku prazna srca darovati ljubav i pomoći im u njihovu traženju smisla života, napose u teškim životnim situacijama bolesti, nemoći ili gubitka najdražih. ${ }^{3} \mathrm{U}$ protekla dva desetljeća porastao je interes za pitanja vjerskog i duhovnog sadržaja u povezanosti s medicinom, kako u znanstvenim krugovima tako i u susretu s bolesnicima. Duhovnost je posljednjih godina postala istraživački fenomen u području medicine. Dok se na znanstvenom polju traga za definiranjem duhovnosti, u medicini je prisutan pragmatičan pristup duhovnosti, ponajprije iz perspektive pacijenta, tj. teži se duhovnost učiniti prepoznatlivivom.

Polazeći od činjenice, da dio bolesnika u palijativnoj skrbi ne pripada niti jednoj konfesiji ili religioznom uvjerenju, tim je teže pronaći odgovarajuću definiciju duhovnosti koja može izreći sve ono što obuhvaća taj pojam u palijativnoj skrbi. Radi osvjetljava ovog pojma, navodim ovdje neke pokušaje definiranja duhovnosti u palijativnoj skrbi. Velik broj znanstvenika definira duhovnost polazeći iz njene praktične upotrebe u palijativi. Pritom oni duhovnost promatraju kao stav pacijenta, njegove rodbine ili djelatnika palijativnog tima $u$ konkretnom susretu čovjeka s neizlječivom bolešću i popratnim kriznim situacijama. ${ }^{4}$ Odjel za dušobrižništvo Njemačkog društva za palijativnu medicinu definira duhovnost kao unutrašnji stav i duhovnu pokretačku snagu čovjeka u traženju smisla života, napose u teškim životnim situacijama. ${ }^{5}$ Prema mišljenju njemačkog liječnika i profesora na Sveučilištu u Witten/Herdecke dr. Arndta Büssinga, duhovnost ovisi o svjetonazoru pojedinog čovjeka te se odnosi uvijek na nematerijalnu stvarnost koja se može iskusiti i koja čovjeku u njegovom življenju pruža bitnu orijentaciju. ${ }^{6}$ Profesor sa Sveučilišta u Bernu dr. Ralph Marc Steinmann promatra duhovnost sa stajališta prevencije zdravlja kao njenu četvrtu dimenziju te je definira kao jedinstvenu egzistencijalnu dimenziju

${ }^{3}$ Usp. Miro JAKOVLJEVIĆ, Duhovnost u suvremenoj medicini i psihijatriji. Profesionalne granice i kompetencije: konceptualna, epistemološka i moralna pitanja, u: isti (ur.), Duhovnost u suvremenoj medicini i psihijatriji, Zagreb, 2010, 7-98, ovdje 8.

${ }^{4}$ Usp. Taugort ROSER, Spiritual care. Organisationale, ethische und spirituelle Aspekte der Krankenhausseelsorge. Ein praktisch-theologischer Zugang, Stuttgart, Münchner Reihe Palliative Care, 2007; Eckard FRICK, Taugort ROSER (ur.), Spiritualität und Medizin. Gemeinsame Sorge um den kranken Menschen, Stuttgart, Münchener Reihe Palliative Care, 2009.

${ }^{5}$ DEUTSCHE GESELLSCHAFT FÜR PALLIATIVE MEDIZIN, www.dgpalliativmedizin.de (05.12.2016).

${ }^{6}$ Usp. Arndt BÜSSING, Niko KOHLS (ur.), Spiritualität transdisziplinär. Transdisziplinäre wissenschaftliche Grundlagen im Zusammenhang mit Gesundheit und Krankheit, Stuttgart, 2011, 195. 
ljudskog bivovanja koja je nošena težnjom za ispunjenim životom i iskustvom smisla. ${ }^{7}$ Definicija Europske udruge za palijativnu skrb (European Association for Palliative Care) glasi:

»Duhovnost je dinamična dimenzija ljudskog života s obzirom na način na koji osobe (pojedinci i zajednice) doživljavaju, izražavaju i/ili traže smisao, svrhu i transcendenciju te na način na koji su povezane s trenutkom u kojem žive, sa samima sobom, s drugima, s prirodom, s onim što je bitno i/ili sveto. ${ }^{8}$

Iz ovih navedenih pokušaja definiranja duhovnosti u palijativnoj skrbi proizlazi da se duhovnost pored ostalih obilježja očituje i kao doživljaj svetoga, uzvišenoga, transcendentnoga. ${ }^{9}$ Ona otvara čovjeku potpuno nov prostor u kojem on postaje svjesniji i sam bliži iskustvu doživljaja da se nalazi "pred tajnom, jednim dubljim shvaćanjem sebe i stvari koje nadilaze naše horizonte $\ll^{10}$ Kao takva ona pruža »osjećaj pripadanja nečemu višem « ${ }^{11}$ koji je istovremeno transcendentan i blizak čovjeku, napose onda kada mu je najteže, npr. u situacijama neizlječivih bolesti. Ova blizina nesumnjivo oslobađa navezanosti da bi čovjek lakše mogao prihvatiti ono što je pred njim, bolest, nemoć kao i sve ono što oni sa sobom nose, pa i samu smrt. Duhovnost pomaže čovjeku da bolest i patnju promatra s drugog aspekta, onog koji oslobađa za nešto drugačije, koje u svojoj biti jest nevidljivo i nerijetko neshvatljivo, teško razumljivo, ali koje u razgovoru i blizini drugoga čovjeka postaje lakše opipljivije, doživljenije i time prihvatljivije. Zato duhovnost u palijativnoj skrbi uključuje uvijek drugog čovjeka, spremnoga pomoći onima koji čeznu za orijentacijom, smislom, ispunjenošću ili/i u konačnici prema transcendentnom ili imanentnom Božjem bivstvu, kojemu je čovjek bitno okrenut, a da nerijetko nije niti svjestan toga.

\section{Filozofsko-antropološka utemeljenost duhovnosti u palijativi - monistički dualizam}

Filozofija, biologija, medicina, psihologija i teologija pokušavaju pomoći čovjeku u bitnim pitanjima njegove egzistencije koja se neprestano pojavljuju u različitim povijesnim vremenima i društveno-političkim uređenjima. Pred pitanjima: Odakle dolazimo? Što radimo? i Kamo idemo? čovjek nerijetko ostaje nijem, ali se ne zadovoljava šutnjom koja progovara prazninom. On traži ne polovičan odgovor nego onaj koji zadovoljava, ispunjava, pruža mir i spokoj nje-

\footnotetext{
7 Usp. Ralph Marc STEINMANN, Spiritualität - die vierte Dimension der Gesundheit. Eine Einführung aus der Sicht von Gesundheitsförderung und Prävention, Münster, 2015, 64.

${ }^{8}$ Ovu definiciju su prihvatili stručnjaci na konsenzusnoj konferenciji o duhovnoj dimenziji u palijativnoj skrbi, koja je 17. i 18. veljače 2009. godine održana u Pasadeni, Kalifornija.

9 Usp. Jakovljević, Duhovnost..., 16 sl.

${ }^{10}$ Marija BABIĆ, Uloga duhovnosti u palijativnoj skrbi, Služba Božja, 53 (2013) 435-440, 439.

${ }^{11}$ Jakovljević, Duhovnost, 14.
} 
govim danima koji su mu darovani da ih živi u zajedništvu s drugima. Susrećući se s tajnom nastajanja i nestajanja, kako je već davno Aristotel govorio, čovjek traga za smislom života. Prema Aristotelu čovjek je prije i nadasve duhovno biće, ali i biće koje je u traženju smisla života i u traženju Boga. ${ }^{12}$ Slijedom ovoga se može zaključiti da je čovjek po svojoj naravi religiozno biće, bio on toga svjestan ili ne, nijekao tu činjenicu ili je priznavao. Za Aristotela je u dvanaestoj knjizi Metafizike »nepokretni pokretač« Bog, kanon svega postojećeg, a posebice ljudskoga života koji iz njega izvire i u nj se vraća. ${ }^{13}$ To iz čega ljudski život izvire i u što uvire moguće je prema Aristotelovu mišljenju razumjeti »kao dijalektički proces nastajanja i nestajanja pri čemu je svako nestajanje, označili ga kao ništavilo ili smrt, početak stvaranja - početak (novog) života«. ${ }^{14}$

Toma Akvinski, kao i Aristotel, promatra čovjeka kao cjelovito biće. Njihov monistički dualizam govori o čovjeku kao duhu (duši), kome je tijelo vanjski izraz i simbol te po tijelu dolazi u dodir s drugima. ${ }^{15}$ Duša i tijelo su, prema njima, sastavljeni samo privremeno. Aristotel daje važnost duši kao čovjekovu životnom principu. Ona je, prema njemu, bit i forma tijela. Prema Tomi, čovjekova duša je sposobna nadživjeti čovjekov ovozemni život. ${ }^{16}$ Aristotel i Toma ponavljaju skoro istu činjenicu, da je ljudska osoba bitno transcendentne naravi. Ona je usmjerena prema savršenosti, apsolutnom dobru, koje je sam Bog. Težnja za uzvišenijim i većim nego što je moguće okom vidjeti ili uhom osluhnuti, kao i hod k ispunjenju i dovršenju, u naravi je svakoga čovjeka.

Uzimajući u obzir ove filozofsko-antropološke postavke proizlazi da se pristup neizlječivom bolesniku u palijativnoj skrbi ne može svesti samo na jedan vid - uklanjanje ili ublažavanje fizičke boli - nego on treba biti holistički, što znači da obuhvaća sve dimenzije ljudskog bića, ponajprije fizičku, psihičku, socijalnu i duhovnu. U palijativnoj skrbi ove četiri dimenzije se međusobno prožimaju, bez obzira s kojeg aspekta se prvotno pristupi bolesniku. Zato i kompetencije osoblja koje radi u palijativi uključuju poznavanje osnovnih postavki medicine, psihologije, filozofije, sociologije, ali i teoloških znanosti.

\footnotetext{
${ }^{12}$ Usp. ARISTOTEL, Metafizika, 980a.

${ }^{13}$ Usp. ARISTOTEL, Metafizika, 970-980.

${ }^{14}$ Dafne VIDANEC, Aristotelova ideja nepokretnog pokretača: komparativno-refleksivni pristup problemu, Metodički ogledi, 18 (2011) 2, 41-67, ovdje 49.

${ }^{15}$ Usp. Karl RAHNER, Zur Theologie des Symbols, u: Schriften zur Theologie, sv. 29, Freiburg in Breisgau, 2007, 305; Emerich CORETH, Was ist der Mensch. Grundzüge einer philosophischen Anthropologie, Innsbruck, 1973, 144-151.

${ }^{16}$ TOMA AKVINSKI, Suma theologia I, 76, 1 ad 4.
} 


\section{Religije - put približavanja odgovorima na čovjekova pitanja smisla života}

Tri velike religije svijeta u svojim doktrinama progovaraju o Bogu i njegovoj objavi čovjeku, o bitnim sadržajima vjere te o smislu čovjekova života, kao i o stvarnostima koje su onkraj smrti.

Za vjernog Židova Bog je stvoritelj svega što postoji. On je židovskom narodu govorio po prorocima. Bog jest sveukupnost moralnih savršenstava, a od ljudi zahtijeva ljubav i pravednost. Židovska vjera se temelji na poslušnosti prema božanskom zakonu koji je sadržan u hebrejskoj Bibliji, ali i u Talmudu (usmena predaja). Središnja tema židovske vjere je u ispunjavanju Božjih zapovijedi, što će donijeti budući život Židovima kao i onima koji to nisu. Prema njihovoj vjeri, Mesija, Božji pomazanik treba doći i opet sakupiti Židove u izraelskoj zemlji. U to vrijeme nastupit će veliko uskrsnuće mrtvih. Židovi vjeruju da pokojnici u miru čekaju Božju presudu koja će se ostvariti na kraju vremena. Svi dobri i pokajnici spasit će se za vječni život, a duše zlih će biti zauvijek uništene.

Prema islamu, obožavanje Alaha u potpunosti daje životu smisao i značenje. Drugim riječima, muslimanova neprekidna svrha je u poslušnosti i pokoravanju Alahu, u izvršavanju njegovih naredbi te u očuvanju stalnog odnosa s njim kroz molitvu, post, milostinju i hodočašće (hadž). Prema islamu, ovaj život je samo prijelazna faza između faze prvog života i faze drugog života. Prvi i drugi život su razdvojeni trenutkom smrti. Način drugog života osoba zaslužuje prema svojim djelima u prvom životu. Na dan suđenja Alah nagrađuje ili kažnjava ljude prema njihovim djelima u prvom životu. Smisao života muslimanima daje vjera u drugi život u kojem se na Sudnji dan ide u raj (dženet). Prema načelima islama, smrt je potpun kraj fizičkog života i početak razdoblja odmora do dana uskrsnuća, kada Alah sudi žive i mrtve. Mnogi muslimani vjeruju da će pravedni moći vidjeti vizije Boga nakon smrti, a zli pakla. Osim tih mogućih vizija raja i pakla, muslimani vjeruju da duša ostaje u nekoj vrsti uspavanosti do Sudnjega dana, kada svatko biva suđen prema svojim djelima.

Kršćanstvo ima korijene u židovstvu. Kršćani vjeruju u Boga koji je sve stvorio, sve uzdržava i svime upravlja. Prema kršćanstvu, čovjek je slika Božja, jedinstvo duha, duše i tijela, biće odnosa, kulturno i političko biće, osoba usmjerena prema nadnaravnome, otkupljeno biće. Glavne kršćanske vjerske istine definirane su na prvim ekumenskim koncilima i uglavnom ih prihvaćaju sve kršćanske vjeroispovijesti. Kršćani vjeruju u jednoga Boga u kojem su tri osobe kao Presveto Trojstvo: Otac - Stvoritelj, Sin - Otkupitelj i Duh Sveti Posvetitelj. Kršćanstvo je religija objave, a čovjek odgovara svojom vjerom na Božji govor u Svetom pismu i u tradiciji Crkvi. Sakramentalni život omogućuje kršćanima rast u milosti i svetosti te im već pruža predokus života s Bogom. Kršćani vjeruju u besmrtnost ljudske duše i uskrsnuće tijela, dok su posljednje 
stvari (raj ili pakao) uvjetovane milošću Božjom i čovjekovim življenjem Evanđelja.

Sa svojim doktrinama ove tri velike religije svijeta pokušavaju pružiti odgovore na pitanja smisla života te mogu bolesniku u palijativnoj skrbi biti od velike pomoći, ako su pripadnici pojedine vjerske zajednice. Osim toga citati iz svetih knjiga, molitva, kao i ostali vjerski obredi imaju veliku terapijsku vrijednost ${ }^{17}$ te pomažu čovjeku da se izdigne iznad svoje bolesti, nemoći, starosti i da u najtežim životnim situacijama živi u nadi, iznad svake nade i ljubavi koja pobjeđuje svaku bol i otire svaku suzu.

Važnu ulogu u životu pripadnika pojedinih religija ima vjera. Ona pomaže čovjeku živjeti sadašnjost, prihvaćati život kao dar od Boga te na njemu bit zahvalan. U iskustvu vjere čovjek već živi one vrijednosti koje su nerazumljive te ostaju predaleke i preteške za one koji ne posjeduju dar vjere. Prema Poslanici Hebrejima vjera je tvrdo (čvrsto) pouzdanje u ono čemu se nadamo, osvjedočenje o onom, što ne vidimo (usp. Heb 11, 1-2). Ono što nas nadilazi ostaje nam uvijek tajnovito i nedohvatljivo, ali upravo je to ono što nas potiče na rad i nadahnjuje ljubavlju prema bližnjima te jamči da će upravo ono što ljudska osoba u svojoj biti jest, nadživjeti ovo vrijeme i otvoriti vrata novom početku, tamo gdje nestaje prolaznost svijeta i vremena. Čovjek koji prepozna duhovnu dimenziju svoga života izdiže se iznad materijalnog svijeta k Onome koji može ispuniti ljudska traženja i dati uvijek više od svih njegovih očekivanja, kako god ga pripadnici pojedinih vjerskih uvjerenja nazivali.

Ukoliko se bolesnik u palijativi izjašnjava kao ateist, potrebno je pristupiti s pažnjom i poštovanjem prema njegovu uvjerenju te mu na dostojanstven i prikladan način pružiti odgovarajuću pomoć, bilo psihološku, socijalnu ili čisto ljudsku ili u pojedinim slučajevima i duhovnu.

\section{Kompetencije duhovnika u palijativnoj skrbi}

Sve ovdje već rečeno daje naslutiti širok spektar kompetencija koje treba posjedovati duhovnik u palijativnoj skrbi. ${ }^{18}$ Suvremeni uvjeti života utječu na produljenje čovjekova života, ali istovremeno zahtijevaju dostojanstven pristup čovjeku u njegovim teškim danima starosti, nemoći ili bolesti. Dostojanstvo pristupa osobama u palijativi pretpostavlja ponajprije općeljudske kompetencije duhovnika, uljudnost, otvorenost i osjetljivost kod prenošenja kulturnih i

\footnotetext{
${ }^{17}$ Jakovljević, Duhovnost..., 78.

${ }^{18}$ Ovaj se odjeljak temelji na sljedećim izvorima: SCHWEIZERISCHE GESELLSCHAFT FÜR PALLIATIVE MEDIZIN, PFLEGE UND BEGLEITUNG, Kompetenzen für Spezialisten in Palliative Care, Bern, 2012; HOSPIZ ÖSTERREICH, Standards für »Seelsorger/in der Hospiz und Palliativversorgung «, Beč, 2012; SCHWEIZERISCHE EIDGENOSSENSCHAFT, Rahmenkonzept Palliative Care Schweiz. Eine definitorische Grundlage für die Umsetzung der Nationalen Strategie Palliative Care, Bern, 2014.
} 
vjerskih vrijednosti. On treba biti čovjek povjerenja, treba znati prije svega slušati i povjerljiv razgovor čuvati tajnom. ${ }^{19} " N$ Negova komunikacija s bolesnikom nužno uključuje jasnu viziju smisla života, te u tom svjetlu otvara prostor za prepoznavanje značenja vlastite bolesti i smrti. ${ }^{20}$ Duhovnik treba zračiti svojom osobnošću, ${ }^{21}$ ali i poznavati različite oblike kultura, tradicija, religioznih uvjerenja ili općecrkvenih načela i vrijednosti koje su za pacijenta od velike važnosti, tj. imati širinu i za one koji nemaju pojam definiranoga Boga (agnostici, ateisti i sl.). Jedno od temeljnih polazišta svakako je poznavanje europske i hrvatske kulturne baštine te u pojedinim situacijama i osnove drugih kultura i religioznih opredjeljenja, kao i društveno-političkih uvjerenja.

Iako su općeljudske kompetencije vrlo bitne, duhovnik pored njih treba imati stanovitu stručnu naobrazbu, barem kao prvostupnik s teološkom diplomom. Nadalje su važne i njegove pastoralne kompetencije, u koje pripada izgrađivanje vlastite duhovnosti i sposobnost izražavanja svoje duhovnosti, poznavanje različitih duhovnosti, iskustvo rada u pastoralu s različitim dobnim skupinama, poznavanje značaja i uloge duhovnosti u pojedinim institucijama u palijativi, u različitim vjerskim zajednicama, u društvu. Isto tako je bitna obredna, ali i etička kompetencija duhovnika.

U postmodernoj kulturi stavlja se u prvi plan prožimanje duhovnog i tjelesnog. Nerijetko se zato od duhovnika očekuje da »djeluje kao iscjelitelj, slično kao liječnik, samo na području duše «. ${ }^{22}$ Zanimljivo je ovdje istaknuti da je Aristotel čovjeka označio kao animal rationale, misleći pritom da je on uvijek na pola puta između vremenitog i vječnog, savršenog i nesavršenog, plemenitog i običnog, dobrog i lošeg. Stoga i svako ljudsko djelo nije i ne može biti savršeno, ali je na putu da vodi k savršenosti, ispunjenju i dovršenju, čemu u biti čezne svaki čovjek, a da toga i nije uvijek svjestan. U palijativnoj skrbi važno je da duhovnik bude svjestan ograničenosti, osobnih, profesionalnih i onih koji se tiču etike. Zato se ne smije razočarati neuspjesima, koji su sastavni dio čovjekova života, nego se nadasve voditi mišlju da je važno sijati, a Gospodin je onaj koji se brine za ostalo.

Za duhovnika u palijativnom timu bitno je poznavanje osnova obrazovanja u drugim disciplinama koje su zastupljene u sustavu palijativne skrbi. On treba poznavati osnove djelovanja svakoga člana palijativnoga tima: opća medicina, psihijatrija, psihologija, onkologija, socijalni rad, rad medicinske sestre i tehničara, rad volontera, ali i mrtvozornika.

Uza sve ovo, duhovnik treba intenzivnije nego ostali članovi tima promišljati o tri vječna pitanja: otkud smo, što tu radimo i kamo idemo? To ne znači da će za svaku situaciju i za svakoga čovjeka pronaći zadovoljavajući odgovor.

\footnotetext{
${ }^{19}$ Usp. Ante MATELJAN, Svećenik i bolesnik, Služba Božja, 4 (2008) 380-407, ovdje 386.

${ }^{20}$ Isto, $390 \mathrm{sl}$.

${ }^{21}$ Valentin POZAIĆ, Čuvari života u pastoralu Crkve, Vjesnik Đakovačke i Srijemske biskupije, 130 (2002) 3, 136.

${ }^{22}$ Mateljan, Svećenik i bolesnik..., 389.
} 
Njegova je zadaća da u svjetlu različitih svjetonazora i shvaćanja smisla života, smrti i patnje, pronađe prikladan pristup ljudima s različitim vjeroispovijestima i svjetonazorima te se i sam nalazi u stalnom traženju, neprestanoj otvorenosti $\mathrm{s}$ ispruženim rukama $\mathrm{k}$ bolesnicima, članovima njihovih obitelji, kao i k onima koji rade u palijativnoj skrbi i trebaju pomoć duhovnika. Matulić ističe važnost kompetencija ili stručnosti u zdravstvenoj skrbi, jer »ona tako može dati izvrsne znanstvene rezultate ${ }^{23}$ Unatoč tome, palijativna skrb se ne smije ovdje zastaviti, nego u nju treba integrirati sve ostale dimenzije čovjekova života, tjelesnu, psihičku, socijalnu, duhovnu... Zato je i spektar kompetencija kao i područja djelovanja duhovnika u palijativnoj skrbi vrlo širok.

Tri su najosnovnija područja djelovanja duhovnika u palijativnoj skrbi. Kao član tima palijativne skrbi duhovnik se brine oko pružanja duhovne pomoći pacijentu, članovima bolesnikove obitelji, kao i kolegama u timu.

Prvo: U odnosu prema pacijentu dolaze do izražaja duhovnikove vještine i vrline kao što su: empatija, umijeće slušanja, savjetovanja, povjerenje i diskrecija. Pristup bolesniku treba biti prožet onom ljubavlju kojom Bog sve ljude prihvaća i ljubi. Umijeće duhovnog praćenja bolesnika u palijativnoj skrbi zahtijeva da duhovnik govori pacijentu njemu razumljivim rječnikom te u simbolima njemu razumljivog iskustva. Komunikacija u simbolima ne obuhvaća samo pozitivne životne simbole nego također i one rubne: sve ono neostvareno u životu, o zahvalnosti i oprostu, pomirenju, kao i učenju puštanja iz ruku. Palijativna skrb pretpostavlja razgovor pun razumijevanja, ali i onaj drugačiji, ovisno o trenutku i stanju pacijenta. On treba prepoznati što osoba traži, kojoj konfesiji pripada ili je nekoga slobodnoga duhovnoga uvjerenja, pri čemu nikada ne bi smio nametati svoja uvjerenja. Važno je da su bolesnici upoznati s mogućnošću primanja sakramenata te, prema želji, umirućem pozvati svećenika, pastora, imama, rabina... Rituali u palijativnoj skrbi imaju svoje posebno mjesto te su pogotovo za dementne osobe od velikog značenja. Njima, i onda kada zaborave smisao riječi pjesama ili molitava, ostane živim smisao za duhovnu zahvaćenost koja se ritualima pokreće.

Drugo: Velik dio dušobrižništva u bolnicama svodi se još uvijek na sakramentalni pastoral: sveta ispovijed, pričest i bolesničko pomazanje, dok su drugi oblici pastorala, npr. duhovni razgovor, kao i veća prisutnost duhovnika u procesu liječenja, vrlo slabo prisutni. ${ }^{24}$ Napose je razgovor važan za članove bolesnikove obitelji, njegove prijatelje i poznanike. Prema članovima bolesnikove obitelji duhovnik osobito iskazuje vrline brižnog tješitelja, dobrog savjetnika i pouzdanog prijatelja. Duhovnik se trsi održati živom međusobnu povezanost bolesnika i članova njegove obitelji, jer je bolesniku najteža napuštenost i ostavljenost od strane najbližih članova obitelji. Bolesnikova rodbina i najbliži

\footnotetext{
${ }^{23}$ Matulić, Identitet..., 741.

${ }^{24}$ Usp. Vladimir DUGALIĆ, Pastoralna skrb u bolnici, Vjesnik Đakovačke i Srijemske biskupije, 130 (2002) 3, 129.
} 
trebaju također ojačati svoju duhovnost da bi mogli pomoći teškom bolesniku. Duhovnik treba prepoznati kada i kakvu duhovnu pomoć treba član obitelji ili neke uže ili šire zajednice. Također on treba imati kulturu palijativne i duhovne skrbi te je znati prenijeti.

Treće: Posao što ga različiti članovi tima palijativne skrbi svakodnevno čine za neizlječivog bolesnika iznimno je naporan i zahtijevan. U palijativnoj skrbi je u središtu bolesnik te je potrebno svim raspoloživim sredstvima tražiti najveću dobrobit bolesnika. Ova dobrobit će nerijetko ovisiti »o usklađenom timskome radu kompetentnih profesionalaca među kojima vlada moralna harmonija i terapijski sklad «. ${ }^{25} \mathrm{Za}$ kvalitetno obavljanje pojedinih službi u timskom radu potrebna je duhovna pomoć kolegama u timu. Duhovnik treba biti kolegijalan, izgraditi suradnički odnos s njima, uvažavati stručnost suradnika, prijateljski podupirati rad u timu. Članovima svoga tima duhovnik je svakodnevna potpora i poticaj u djelatnosti koja će trajno biti u opasnosti podcjenjivanja te smatrana nekorisnom i štetnom. Pored brige za duhovnost članova tima, duhovnik treba sudjelovati u seminarima i kongresima koje organizira stručno vodstvo palijative.

Za sve ovo, potreban je dodatni odgojno-obrazovni proces ili studij za duhovnika u palijativnoj skrbi. Također je bitno naglasiti i potaknuti odgovorne na našim studijima o integriranju duhovnosti u cjelokupan sustav studija. Osim toga, i teološki fakulteti bi trebali što prije prepoznati važnost odgoja duhovnika u palijativnoj skrbi. Odgoj za ovu vrstu pastorala »treba svakako biti interdisciplinaran, kako u prenošenju potrebnih znanja, tako i u uključivanju u mrežu suradnika, posebno vjernika laika koji već djeluju u okviru medicinske skrbi, te dragovoljaca, bez kojih je ozbiljni pastoral bolesnika nezamisliv«. ${ }^{26}$

\section{Zaključak}

U nekim etapama svoga života, napose u susretu s bolesti te sa svojom ograničenosti, smrti, starosti ili nemoći izranjaju na površinu pitanja o smislu života, patnje i smrti. U ovakvim situacijama čovjek treba pomoć drugih, svojih najbližih, prijatelja, liječnika, psihologa, ali i duhovnika. Duhovnost je po samoj naravi stvari u palijativnoj skrbi njen sastavni dio. Ona ima svoje utemeljenje prvenstveno na zadanostima filozofske antropologije koja promatra čovjeka u njegovoj tjelesnoj, psihičkoj i duhovnoj dimenziji te naglašava njegovu transcendentnost i traganje za višim i uzvišenijim, što mu ovaj materijalni svijet ne može pružiti. Cilj duhovnosti u palijativi je pomoć ljudima bilo kojeg svjetonazora ili vjerskog uvjerenja u njihovu traganju za ispunjenjem, kao i za

\footnotetext{
${ }^{25}$ Matulić, Identitet..., 732.

${ }^{26}$ Snježana KRALJEVIĆ-ČILIĆ, Prikaz bolničkog dušobrižništva u Đakovačkoj i Srijemskoj biskupiji, Vjesnik Đakovačke i Srijemske biskupije, 130 (2002) 3, 148-151.
} 
smislom života, patnje i smrti. Ona je specifična po pristupu čovjeku različitih vjeroispovijesti i svjetonazora.

Uloga duhovnika u palijativnoj skrbi je neizmjerno važna. On pomaže čovjeku u njegovim u egzistencijalnim, duhovnim i vjerskim potrebama. Vrlo je bitan pojedinačni pristup svakoj osobi, tj. onaj koji uzima u obzir njene determiniranosti poviješću, socijalnim, kulturnim i drugim određenjem te vjerskim (ne)opredjeljenjem. S dubokim poštivanjem svih tih odrednica, koje oblikuju čovjeka kao osobu, bitno je uzeti u obzir činjenicu da je čovjek neprestani tražitelj Boga, smisla, života, sreće te da postoje u njemu težnje i traženja one iskonske povezanosti s nevidljivim Stvoriteljem - s kojim pripadnici različitih religija imaju njima specifične načine komuniciranja. Zanemarivanje bilo koje od ovih činjenica izaziva opće nezadovoljstvo ne samo pacijenata nego i djelatnika u palijativnoj skrbi. Zato kompetencije duhovnika u palijativnoj skrbi imaju širok i raznolik spektar. Pristup bolesniku, uvažavanje različitih oblika duhovnosti te pružanje ponajprije duhovne pomoći svima koji je trebaju, pacijentima, njihovoj rodbini kao i osoblju u palijativnom timu, utječe na kvalitetu života bolesnika u palijativi, ali i rada palijativnog tima. 
Vinka Bešlić*

The spirituality and the spiritual assistant in the palliative care

Summary

Beginning with the term of spirituality in the palliative care, this article, based on the philosophical - anthropological awareness of monistic dualism, as well as on the basic foundations of three major world religions on human living and his direction to God, wishes to enlighten the importance of the spirituality, as well as of the spiritual assistant in the palliative care. The spirituality represents one important part of the total care of dignity of human life in one of the hardest situations when illness or old age comes. The increased interest for spirituality in general, especially in medicine, once again confirms the importance of the holistic approach to humans in the palliative care. The monistic dualism is emphasising the interaction between the spirit, soul and body in human living. This shows that the spiritual dimension has very important role. Three major world religions, each in its own particular way, confirm this interaction of the spirit, soul and body when it comes to human life and death, as well as to the spiritual values that are beyond human earthly life. The presence of the spiritual assistant is important in the palliative care; who will try to help one person facing extremely difficult situation for him and for his family, who will try to be close to them, listen to them, understand them and try to help them discover genuine, eternal values. That is how the spiritual assistant with his competency and experience, becomes available not only to the person in the palliative care, but to his relatives and stuff employed in the palliative care team.

Key words: spirituality, philosophical - anthropological grounds, competency of the spiritual assistant, palliative care, religion.

(na engl. prev. Janja Boras)

\footnotetext{
* Vinka Bešlić, PhD, Systematic Study of Spirituality, Address: Česmičkoga 1, HR-10000 Zagreb, Croatia; E-mail: s.vinka.beslic@gmail.com.
} 